\title{
“ROCKET TO ROCKET": SEBUAH KISAH TENTANG CITA-CITA DAN HARAPAN
}

\author{
Yholanda Kunthi Anggriva ${ }^{1}$, Mahendradewa Suminto ${ }^{2}$, Agnes Karina Pritha \\ Atmani $^{3}$ \\ Program Studi Animasi, Fakultas Seni Media Rekam, Institut Seni Indonesia \\ Yogyakarta \\ yholandakunkun@gmail.com ${ }^{1}$, mahendrads@gmail.com², \\ agneskarina@gmail.com ${ }^{3}$
}

\begin{abstract}
Abstrak
Roket merupakan wahana luar angkasa, peluru kendali, atau kendaraan terbang yang mendapatkan dorongan melalui reaksi roket terhadap bahan fluida. Dalam film ini, roket mewakili mimpi dan harapan. Proses meluncurnya roket adalah proses seseorang mencapai mimpinya. Proses meluncurkan misil ke luar angkasa memang tidak mudah, namun bukan berarti tidak bisa. Film ini, mengajak penonton untuk yakin akan harapan dan berani memperjuangkannya. Penciptaan film animasi ini disajikan dalam bentuk animasi 2D (dua dimensi) tanpa menggunakan narasi atau dialog. Sebagai pendukung suasana dibuatlah musik yang dapat membangun suasana. Tidak lupa 12 prinsip animasi diterapkan dalam film animasi ini untuk memperkuat dan menambah kesan artistik sebagai penunjang visualisasi. Teknik animasi dua dimensi sengaja digunakan karena bentuk visual dari animasi 2D (dua dimensi) memiliki kesan yang ringan namun mudah di ingat.
\end{abstract}

Kata Kunci : impian, roket, harapan, animasi 2D

\begin{abstract}
Rockets are spacecraft, missiles, or flying vehicles that get a boost through rocket reactions to fluid materials. In this film the rocket represents dreams and hopes. The process of launching a rocket is the process of reaching someone's dream. The process of launching missiles into space is not easy, but that doesn't mean it can't. This film, invites the audience to be sure of hope and dare to fight for it. The creation of this animated film is presented in the form of $2 D$ animation without using any narration or dialogue. As a support for the atmosphere, music is created that can build an atmosphere. Not forget the 12 principles of animation applied in this animated film to strengthen and improve the artistic impression as a support of visualization. The two-dimensional animation technique is intentionally used because the visual form of $2 D$ animation has a light but easy to remember impression.
\end{abstract}

Keywords: dreams, rockets, hope, 2D animation. 


\section{PENDAHULUAN}

\section{Latar Belakang}

Setiap orang pasti memiliki harapan atau cita-cita. Sebagai anak-anak, mempunyai cita-cita dan membayangkan akan menjadi apa saat dewasa nanti adalah hal yang menakjubkan. Orangtua pasti memiliki keingingan dan harapan yang terbaik untuk buah hati mereka. Namun, orangtua terkadang lupa bahwa anak juga memiliki keinginan, impian dan harapan mereka sendiri. Komunikasi yang kurang baik antara orangtua dan anak adalah salah satu penyebab terjadinya kasus ini. Mengangkat pokok permasalahan ini, munculah gagasan untuk menjadikan permasalahan ini sebagai kosep utama dalam penciptaan karya film animasi. Teknik animasi dua dimensi sengaja digunakan karena bentuk visual dari animasi 2D (dua dimensi) memiliki kesan yang ringan namun mudah diingat. Selain itu mempertimbangkan sumberdaya manusia, peralatan yang digunakan serta waktu pengerjaan, teknik animasi 2D (dua dimensi) adalah teknik yang paling sesuai dalam proses produksi film animasi.

\section{Rumusan Masalah}

Berdasarkan latar belakang, dapat dirumuskan permasalahan yang akan diselesaikan sebagai berikut :

1. Menyuguhkan masalah sosial antara orangtua dengan anak untuk menjadi sebuah film animasi dua dimensi.

2. Memproduksi dan menerapkan teknik animasi dua dimensi untuk menciptakan film animasi "Rocket to Rocket".

\section{Tujuan}

Tujuan dari penciptaan film animasi 2D "Rocket to Rocket" antara lain :

1. Menyuguhkan film animasi dengan membawa pokok masalah antara orangtua dan anak yang dikemas dengan menggunakan unsur cerita imajinatif,

2. Memproduksi animasi "Rocket to Rocket" dengan teknik digital dua dimensi. 


\section{Target Audien}

Target audien menurut demografis film ini adalah ;
1. Usia
: 14 tahun keatas
2. Jenis kelamin : Laki-laki dan perempuan
3. Pendidikan : Dari latar pendidikan apapun
4. Status sosial : Semua kalangan

\section{Indikator Capaian Akhir}

Hasil akhir animasi "Rocket to Rocket" adalah :
1. Judul Karya
: Rocket to Rocket
2. Teknik : Animasi Digital 2D (dua dimensi)
3. Desain Karya : Film Animasi
4. Durasi : 00:05:18:00
5. Format Video : HDTV $1920 \times 1080$ px 24 frame per second
6. Render : format .mp4, H264 dan .MOV

Indikator yang dicapai dalam pembuatan animasi "Rocket to Rocket" dibagi menjadi tiga tahapan, yaitu praproduksi, produksi, dan pascaproduksi.

\section{LANDASAN TEORI}

\section{Animasi}

Animasi berasal dari bahasa latin, yakni anima yang artinya jiwa, hidup, nyawa, dan semangat. Dalam bahasa Inggris, animasi diambil dari kata animate yaitu menjiwai atau menghidupkan (Aditya, 2007). Animasi dapat didefinisikan sebagai ilusi adanya gerakan yang dicapai dengan menampilkan sederetan gambar secara cepat yang memiliki sedikit perbedaan antara yang satu dengan yang lain.

\section{Konflik Antara Anak dan Orangtua}

Konflik anak dengan orangtua memang wajar terjadi. Perbedaan usia, visi, hingga sudut pandang adalah beberapa hal yang kadang mendasari timbulnya konflik. Kartadinata (1998) mengartikan bahwa hubungan keakraban orangtua 
dalam keluarga adalah sebagai suasana psikologis yang dirasakan dan berpengaruh terhadap pola perilaku individu (anggota keluarga).

\section{Roket}

Roket merupakan wahana luar angkasa, peluru kendali, atau kendaraan terbang yang mendapatkan dorongan reaksi yang sangat cepat antara roket terhadap keluarnya fluida dari mesin roket. Reaksi dari pembakaran ini mampu membuat gas mengalir dengan kecepatan hypersonic sehingga menimbulkan dorongan reaktif yang besar sehingga roket dapat lepas landas ke angkasa (Voice, 2018).

\section{PERANCANGAN}

\section{Sinopsis}

Sore itu Lina dibawa oleh sang nenek untuk tinggal bersamanya setelah kepergian orangtua Lina. Setelah beberapa jam perjalanan sampailah mereka di rumah nenek. Tanpa bantuan pun Lina langsung membawa kopernya masuk. Selama ini Lina belum pernah mengunjungi neneknya. Jadi rumah itu masih asing baginya. Suasananya sedikit membosankan. Ornamen lama dan foto orangtua Lina terpajang di lorong.

Lina menempati sebuah kamar yang sepertinya sudah lama tidak ditempati. Beberapa kardus berisi barang-barang lama, masih tersimpan disana. Lina langsung merebahkan diri di kasur, menghela nafas karena lelah setelah perjalanan yang jauh. Saat melihat ke langit-langit, Lina dikejutkan dengan ornamen bintangbintang yang masih tertempel dengan rapi. Sepertinya kamar ini milik ayah Lina saat masih kecil dulu. Teringat dengan orangtuanya, Lina membuka koper dan mengambil selembar foto dirinya dengan ayah dan ibu. Tanpa disadari, Nenek mengetuk pintu dan sudah berdiri di depan kamar. Nenek membawa setumpuk buku dan alat belajar lainnya. Tanpa menghabiskan waktu, nenek membuat Lina sibuk dengan buku-buku yang harus ia pelajari. Buku-buku itu semakin bertambah dan membuat Lina kelelahan. Saat Lina melihat ke bawah, ia pun teringat telah 
membawa roket mainan disakunya. Secara sembunyi-sembunyi Lina mengambil roket itu disaat nenek yang sedang membaca buku di depan Lina, tidak memperhatikan Lina. Karena senangnya, Lina tertawa kecil sambil memainkan roket itu. Namun, ternyata nenek melihat apa yang dilakukan Lina. Kemudian nenek mengambil roket itu dari tangan Lina.

Lalu nenek memberi Lina hukuman dengan tidur lebih awal. Lina yang sedih karena roket kesukaannya diambil, hanya bisa terbaring di kasur. Saat sedang berusaha untuk tidur, Lina merasa ada sesuatu yang jatuh di dekat kepalanya. Saat ia menolehkan kepala, ternyata itu adalah sebuah bintang kecil. Bintang itu memancarkan cahaya redup. Saat melihat ke langit-langit, semua bintang yang ada diatas tadi menyala menerangi kamar Lina yang gelap. Lina beranjak dari kasur kemudian menyiapkan ancang-ancang untuk melompat. Lina berusaha menggapai bintang-bintang itu. Kemudian badan Lina mulai melayang, seakan-akan sedang berada di luar angkasa. Lina terbang mengelilingi bintangbintang itu. Lina seketika berada di luar angkasa yang penuh bintang. Kemudian beberapa bintang mulai bergerak menuju satu titik. Saat diamati ternyata itu adalah sebuah pesawat luar angkasa yang sangat besar. Tanpa pikir panjang Lina melompat dengan berpijak dari satu bintang ke bintang lainnya untuk melihat lebih dekat. Karena bahagia melihat pesawat itu Lina berusaha melompat semakin cepat. Semakin dekat, semakin terlihat besar pula pesawat itu. Lina mengulurkan tangannya sejauh mungkin untuk meraih pesawat itu. Saat hampir menyentuhnya, Lina terjatuh.

Layaknya gravitasi kembali seperti di bumi. Lina terjatuh di depan almari tua. Memegang sebuah roket asing di tangannya sambil terduduk disana. Tanpa disadari nenek sudah datang membuka pintu dan menyalakan lampu. Walau kelihatan marah tapi nenek hanya menghela nafas. Nenek memandangi roket yang ada di tangan Lina, kemudian mencoba untuk mengambilnya. Lina tak rela roket lain diambil darinya. Nenek sedikit terkejut dengan reaksi Lina. Setelah menghela nafas nenek melihat kembali kearah Lina lalu ke roket yang ada di tangannya. 
Tangan nenek bergerak kearah roket itu. Namun bukan untuk mengambilnya, melainkan jari telunjuknya mengarah kearah roket. Menunjukan sesuatu yang tidak Lina sadari. Ternyata itu adalah sebuah tabung. Setelah dibuka, di dalam roket itu terdapat sebuah foto. Itu adalah foto ayah Lina saat masih kecil. Bermain dengan roket itu dan disampingnya ada nenek. Ternyata saat masih kecil ayah Lina bercita-cita menjadi astronot. Sekarang Lina mendapat kepercayaan dari sang nenek untuk melanjutkan cita-cita sang ayah.

\section{Desain Karakter}
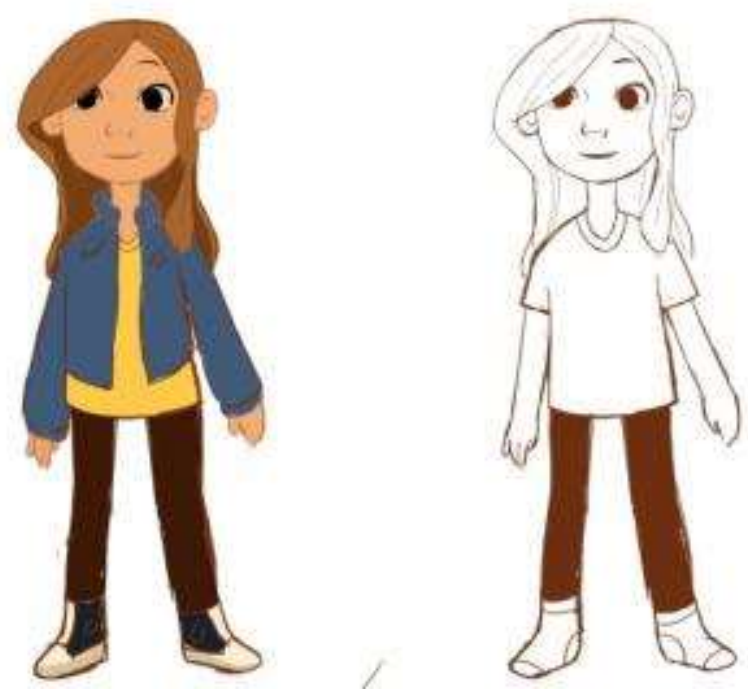

Gambar 1. Desain karakter tokoh utama "Lina".

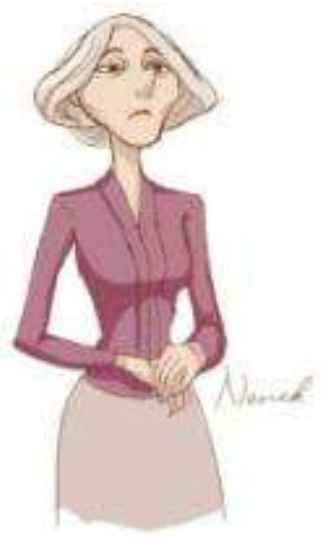

Gambar 2. Desain karakter tokoh "nenek". 


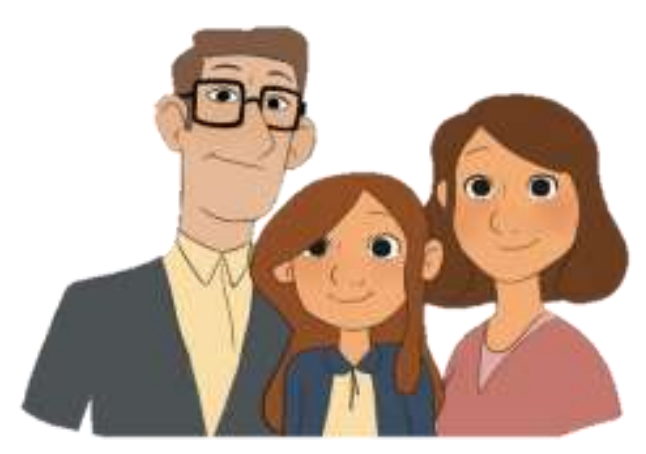

Gambar 3. Desain karakter "Ayah dan Ibu Lina".

\section{Storyboard}
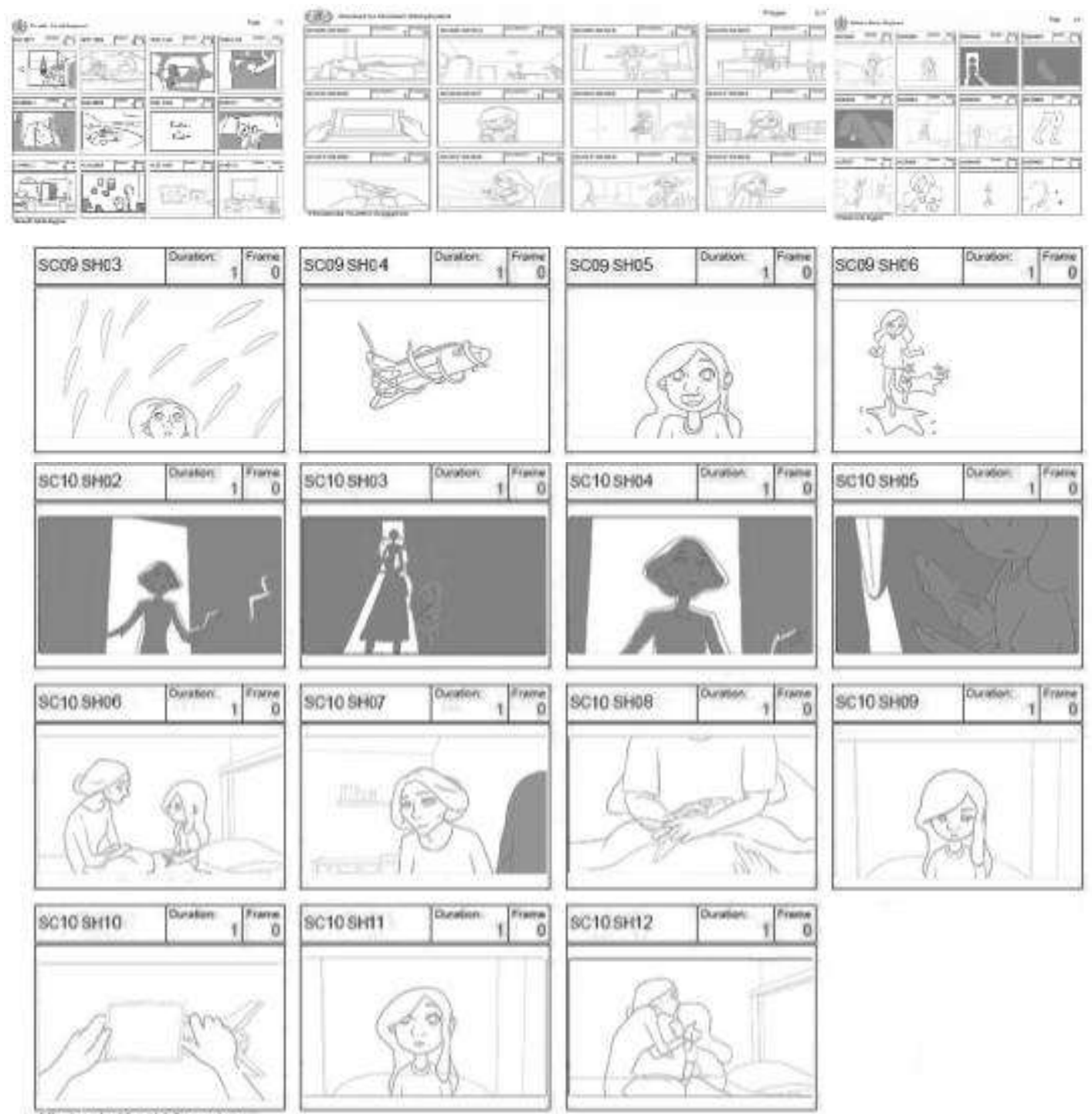

Yholanda Kunthi Anggrva

Gambar 6. Storyboard film animasi 2D (dua dimensi). 


\section{PERWUJUDAN}

\section{Praproduksi}

Praproduksi dilakukan melalui animatic storyboard. Dalam proses animatic stroryboard keseluruhan durasi dan semua gerakan animasi sudah ditentukan. Tahapan yang dilakukan adalah membuat gambar sketsa key frame yang telah dirancang kemudian di-compositing sehingga seluruh shot tergabung menjadi satu film. Warna yang digunakan dalam animatic storyboard pada animasi ini hanya hitam, putih dan abu-abu. Warna tersebut untuk membedakan lighting dan shading.

\section{Produksi}

a. Animating

Proses animating pada film animasi "Rocket to Rocket" menggunakan teknik digital frame by frame. Waktu yang digunakan untuk proses animating cukup lama, karena pada animasi "Rocket to Rocket” terdiri dari 66 shot. Ukuran gambar yaitu 2000 x 1100 pixel dengan resolusi 100 dpi dengan format export yaitu sequence image png. atau jpeg. sesuai kebutuhan tiap adegan.

b. Clean Up

Pada proses ini yang dilakukan adalah memastikan tidak ada garis yang terlewat, lebih, atau kurang. Tujuan dari proses ini adalah untuk menjaga kerapian dan mempermudah pada saat proses pewarnaan. Pada proses ini software yang digunakan adalah TVPaint.

\section{c. Coloring}

Proses pewarnaan pada animasi ini menggunakan software yang sama yaitu TVPaint. Waktu yang diperlukan untuk proses pewarnaan cukup lama, karena teknik pewarnaan menggunakan shading atau bayangan pada karakter yang bergerak. Pada proses ini terdapat beberapa tahapan yaitu layer garis atau line out, layer warna dasar, lalu layer shadow atau bayangan. 


\section{Pasca Produksi}

a. Compositing

Proses compositing adalah proses penggabungan antara beberapa frame inbetween yang sudah dibuat dengan background, sound effect, dan musik latar. Composition setting diatur sesuai durasi yang dibutuhkan dalam satu shot. Ukuran layar yang digunakan adalah HDTV 1980 x1080 px frame rate 24 fps.

b. Scoring

Scoring music dibuat mengacu pada mood, suasana atau jalan cerita animasi "Rocket to Rocket".

\section{c. Editing}

Editing adalah proses meng-edit seluruh shot yang sudah tersusun sesuai timing naskah dari opening hingga ending. Kemudian pada proses editing disini hanya penambahan seperti transisi, pengaturan kamera yang kurang sesuai dan pengaturan sound. Setelah proses editing selesai maka dilakukan rendering final dengan format HDTV 1980 x 1080 px dalam bentuk video $\mathrm{H} 264$.

\section{d. Mastering}

Karya telah selesai dibuat kemudian di burn ke dalam piringan DVD dengan packaging DVD case berwarna transparant sebanyak tiga copy.

\section{Pembahasan Isi Film}

\section{Preposisi}

Pada bagian awal film menunjukkan tokoh utama yang sedang bermain dengan roket di mobil saat dalam sebuah perjalanan. Adegan ini ingin menjelaskan bahwa tokoh utama adalah seorang anak kecil bernama Lina yang suka dengan roket dan bercita-cita ingin menjadi seorang angkasawan. Pada adegan saat sang nenek melihat ke arah Lina, kemudian ia berhenti bermain roket. 
Adegan ini menunjukkan bahwa sang nenek adalah karakter yang tegas dan sebagai seorang cucu Lina patuh pada neneknya.

\section{Konflik}

Konflik dalam animasi ini ditunjukkan saat nenek meminta Lina untuk belajar namun saat di tengah proses belajar ia bermain dengan roketnya. Sang nenek marah dan mengambil roket Lina, lalu nenek menyuruh Lina untuk tidur lebih awal. Adegan ini ingin menunjukkan bahwa sang nenek tidak suka karena Lina memiliki cita-cita sebagai angkasawan.

\section{Resolusi}

Resolusi dijelaskan ketika nenek melihat Lina terduduk di lantai sambil memegangi sebuah mainan roket lain. Saat nenek mencoba untuk mengambil roket itu Lina menolak. Kemudian nenek menunjukan kepada Lina bahwa roket tersebut menyimpan sesuatu di dalamnya. Saat dibuka ternyata di dalam roket itu terdapat sebuah foto. Foto tersebut adalah foto ayah Lina saat masih kecil yang sedang bermain roket bersama nenek. Nenek tersenyum ke arah Lina dengan lembut lalu mengecup dahinya. Sekarang Lina mendapat kepercayaan dari sang nenek untuk melanjutkan cita-cita sang ayah menjadi angkasawan.

\section{PENERAPAN 12 PRINSIP ANIMASI}

\section{Squash and Stretch}

Prinsip ini menerangkan bahwa sebuah objek memiliki volume tertentu, yang kemudian mempengaruhi fleksibilitas dan elastisitas dari objek tersebut. Dalam film animasi "Rocket to Rocket" prinsip ini ditunjukan pada adegan saat Lina terkesima melihat roket di luar angkasa lalu berusaha mendekatinya.

\section{Straight Ahead and Pose to Pose Action}

Straight ahead merupakan metode pembuatan animasi secara spontan dari frame awal hingga frame akhir menjunjukkan satu rangkaian gerakan yang sangat jelas maksud dan tujuannya. Prinsip ini ditunjukkan pada adegan munculnya pesawat luar angkasa. Sedangkan pose to pose adalah metode penganimasian yang 
sudah direncanakan secara matang dengan menggunakan beberapa key drawing sebagai gambar kunci. Contohnya seperti pada adegan

\section{Anticipation}

Prinsip ini digunakan sebagai persiapan kepada sebuah gerakan yang akan dilakukan. Prinsip ini diterapkan pada adegan saat Lina akan melompat dari kasur untuk meraih bintang-bintang.

\section{Slow in and Slow Out}

Slow in and slow out menegaskan kembali bahwa setiap gerakan memiliki percepatan dan perlambatan yang berbeda-beda. Slow in terjadi jika sebuah gerakan diawali secara lambat kemudian menjadi cepat. Sedangkan slow out terjadi jika sebuah gerakan yang relative cepat kemudian melambat. Penerapan prinsip ini ditunjukan pada adegan saat Lina terjatuh dari luar angkasa.

Arcs

Setiap gerakan pada objek atau karakter akan selalu membentuk sebuah pola atau jalur lengkung yang disebut arcs. Pengaplikasian prinsip ini ditunjukkan pada adegan nenek memasuki kamar Lina.

\section{Secondary Action}

Prinsip ini merupakan penambahan gerakan pendukung atau pemanis yang akan menambah dan memperkaya gerakan utama. Salah satu adegan yang menggunakan prinsip ini adalah adegan saat Lina dan sang nenek sedang berjalan menuju rumah.

\section{Follow Trough and Overlaping Action}

Prinsip ini menunjukkan sebagian dari tubuh karakter ataupun objek lain dalam suatu pergerakannya, masih mempertahankan pergerakannya pada saat karakter ataupun objek berhenti dari gerakan awalnya. Sedangkan overlapping action adalah ketika ada gerakan sebagian objek atau karakter yang seakan tertahan dan tertarik ke arah lain dari arah gerakan utama karakter atau objek, dan seolah-olah menutupi gerakan sebelumnya. Adegan yang menunjukkan prinsip ini 
adalah saat Lina melompat dari satu bintang ke bintang lainnya. Rambut Lina menunjukkan prinsip follow trough dan overlapping action.

\section{Solid Drawing}

Prinsip penting yang perlu diterapkan untuk menciptakan animasi yang konsisten. Berfungsi untuk memberikan kesan sebuah karakter atau objek memiliki dimensi, bentuk, volume, dan berat yang utuh. Prinsip ini dipakai pada hampir semua adegan dalam film "Rocket to Rocket". Contoh salah satu adegan yang menggunakan prinsip ini adalah saat Lina melompat menuju ke luar angkasa.

\section{Timing and Spacing}

Timing adalah pembagian waktu yang menentukan cepat lambat pada gambar. Sedangkan spacing adalah untuk menentukan kepadatan frame yang nanti akhirnya akan menentukan kecepatan gambar.

\section{Staging}

Prinsip ini mirip seperti di pementasan atau teater. Intinya, menegaskan posisi seorang aktor terhadap unsur-unsur seperti penempatan tokoh, penggunaan cahaya, dan sudut pandang kamera. Pengaplikasian prinsip ini salah satunya terdapat pada adegan saat nenek dan Lina berjalan memasuki rumah.

\section{Appeal}

Appeal berkaitan dengan keseluruhan look atau gaya visual dalam animasi Style dari sebuah karya animasi dapat langsung dikenali hanya dengan melihatnya sekilas.

\section{Exagerration}

Prinsip exaggeration bertujuan untuk memberikan kesan berlebih agar menciptakan kesan hiperbola dan dramatis. Prinsip ini dapat diterapkan dalam menciptakan suatu ekspresi, gerakan maupun pose suatu karakter. 


\section{KESIMPULAN}

Penciptaan film animasi "Rocket to Rocket" telah terlaksana sesuai indikator capaian yang telah ditentukan. Pembuatan karya tugas akhir animasi "Rocket to Rocket" bahwa penciptaan film animasi "Rocket to Rocket" telah selesai dengan pesan yang tersampaikan dalam durasi 5 menit 17 detik. Selain itu, tercapai 64 shot untuk menyampaikan cerita dengan total 5.760 frames, dengan format HDTV 1920 x 1080px 24fps (frame per second) untuk menghasilkan kualitas gambar yang baik. Dalam animasi ini, penggunaan 12 prinsip animasi juga telah diterapkan sesuai ketentuan.

Dari hasil yang telah dicapai sesuai proses penciptaan animasi "Rocket to Rocket" ini, ada beberapa catatan yang dapat diterapkan pada perancangan serupa. Pertama, sebelum memasuki proses produksi karya memerlukan riset yang cukup, agar karya dapat dipertanggungjawabkan. Kemudian menyempatkan diri untuk melakukan brainstorming dan menambah referensi karya yang dapat menginspirasi pada karya dapat dilakukan. Terakhir, berdiskusi dan meminta saran serta kritik dari orang lain mengenai karya yang sedang kita buat, baik dengan teman animator atau orang awam. 


\section{DAFTAR PUSTAKA}

Aditya. (2007). Trik Dahsyat Menjadi Animator 3D. Yogyakarta: Penerbit Andi.

Kartadinata, S., \& dkk. (1998). Bimbingan di Sekolah Dasar. Bandung:

Departemen Pendidikan dan Kebudayaan.

Voice. (2018, November 9). Pesawat ulang-alik. Retrieved December 27, 2018, from Wikipedia:

https://id.wikipedia.org/w/index.php?title=Pesawat_ulangalik\&stable $=0 \&$ redirect $=$ no 